\title{
功物の大腿骨頭径と体重のアロメトリ*
}

\author{
馬判 清 資*1, 藤 江 裕 道*2, 佐 納 義 久*3
}

\section{Allometry of Femoral Heads of Animals with Their Body Weight}

\author{
Kiyoshi MABUCHI, Hiromichi FUJIE and Yoshihisa SANOU
}

\begin{abstract}
In the present study, the relationship between the femoral head diameter and the body weight of animals is shown. The diameter of femoral heads of fifteen terrestrial mammalian animals were measured directly from their skeletons. The body weight of these animals was referred from literature. Additionally, both the mean values of the femoral head diameters and the body weights of Japanese adult men and women were referred from the literature. The logarithm of femoral head diameter of these animals were plotted against the logarithm of body weight. The positive correlation was significant $(p<0.01)$. The gradient of the regression line was 0.29 . It showed that femoral head diameter is proportional to (body weight) ${ }^{0.29}$. By analysis, we showed that this relationship can be deduced from the condition of uniform contact pressure or uniform performance of squeezed-film lubrication.
\end{abstract}

Key Words: Biomechanics, Tribology, Bearing Strength, Allometry, Femoral Head

\section{1. 䋖}

動物の体の, 大きさと形の因果関係を最初に指摘し たのは, Galileo Galilei(1638)である(1). 彼は, 生活形 態が類似した動物を比べると，体格の大きい動物ほど 足の骨が太短かくズングリしている，と述べている.

もし，異種の動物の体がすべて相似形であれば，そ の底面すなわち足の裹に加わる圧力は，背の高さに比 例して一義的に決まる，足の支える圧力には限界があ るので, 高さにも限界が生じる。しかし，実際の動物の 体には支持する部分, 四肢, と支持される部分，〈幹， 頭部，頸部，という機能分担がある.よって，支持する 部分のみ，つまり，四肢の骨の断面積を広げることに より体格の向上が可能となる，その場合，図1のよう に，足が太短かくなる。

このような大きさと形の因果関係の考察は, アロメ トリと呼ばれる(2).アロメトリは，工学分野のスケー リングと類似している.ただし，スケーリングは，設計 方針を立てるのに用いられるのに対して，アロメトリ

*原稿受付 平成 3 年 12 月 2 日.

*1 正员, 北里大学医学部 (⿶228 相模原市北里 1-15-1).

*2 正累, University of Pittsburgh(M 272 Scaife Hall, 3550 Terrace Street, Pittsburgh, PA 15261, USA).

*3 学生員, 東京工業大学大学院総合理工学研究科(8227 借浜 市緑区長津田町 4259).
は，動物の体の設計方針を探るために用いられるとい う相違がある。

従来, 運動器官のアロメトリに関して, 鳥の体重と
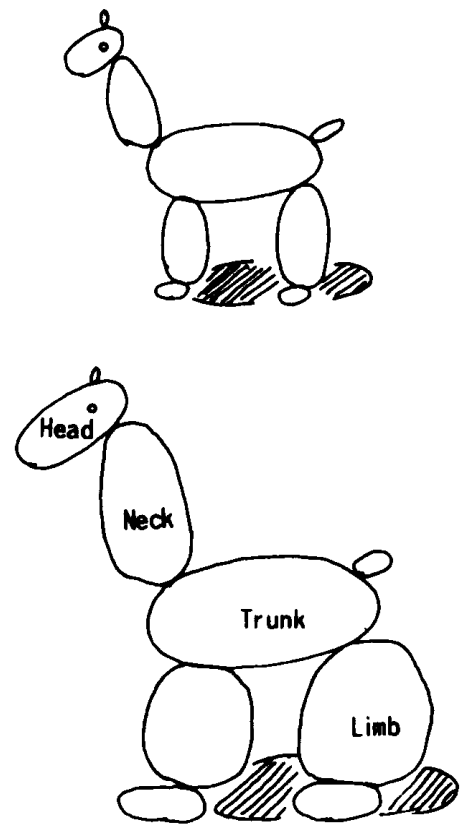

図 1 動物の体の役割分担

（大きな体を支えるには太い足が必要となる） 
はばたき周期の関係(2), 四肢の骨の周囲長と体重の関 係(3) などが, 調べられている.これらの研究の成果か ら，体重の大き過ぎる鳥は，はばたけないとか, ブラ キオサウルスの体重は, $70 \mathrm{t}$ 程度であったといった結 果が, 示されている.

本研究のテーマ, 関節部分のアロメトリについては, Simon (1970)が, 数種の動物の軟骨の厚さおよび接触 圧力について調へている(4)。そして, 接触圧力がア口 メトリの因子だと推定している。しかし，調査対象が 少なく結果のパラツキも大きいため, 明確な結論を示 すにはいたっていない.

関節の摩擦は，極めて低いので(5)，運動方向に治っ たねじりや曲げのモーメントが，外力として骨頭に加 わることはない. そのため, 運動自由度の大きな股関 節や肩関節の骨頭部分は，すべての方向の曲げやねじ りを受けないという特殊な力学環境に置かれている。

一方，接触圧力や潤滑の問題が関節のサイズに関係す る.また，下肢の関節は，七トの直立二足步行の特殊性 を考察する上て, 重要な部分になる.こうした理学的 な興味以外に, 関節のサイズの問題は, その代替材料 である人工関節の設計という実用上の問題に大きく関 つている.

本研究では，股関節の大腿骨頭径を夷測し，文献お よび実測で求めた体重との相関を求めた。その結果を 基に，関節の大きさを決定する因子を推定した。そし て, 以上に述べた理学的, 実用的な諸問題について考 察した。

\section{2. 諸因子の推定}

あらかじめ, 関節のアロメトリに関係する力学的因 子について考察しておく．ただし，股関節に加わる荷 重は, 動物の体重 $w$ に比例すると考え，比例定数を， $k$ とした。

$2 \cdot 1$ 棈成材料の物性 関節の構成材料である海 綿骨や軟骨の物性は，それを表現する方法そのものが 模索されている状態であり ${ }^{(6)}$ ，簡単な定量は困難であ る.しかし，海綿骨の構造は，カルシウムアパタイトが 骨梁構造をなしている点(7)で,すべての動物種に共通 である。また，軟骨についても材質に種差はなく( ${ }^{(8)}$ 物 性の実測(9)でも，種差は明確にされていない。さらに， 皮質骨の圧縮強度の種差はわずかであることが示され ている(10).これらのことから，本研究では，材料強度， 弾性係数に動物種による差異はないとした。

$2 \cdot 2$ 圧編, せん断に対する強度圧縮強度やせ ん断強度は，断面穔に比例して增大する。よって、これ らを因子とすれば，大腿骨頭径は，体重の平方根に比
例するはずである，骨頭直径を $d$ と置くと，次式が成 り立つ。

$$
d \propto(k w)^{1 / 2} \propto w^{1 / 2}
$$

2.3 间節面の接触圧力 接触圧力は, 必ずしも 見掛けの接触面稘によっては決まらない。一般に，二 次曲面同志の弾性接触の場合，接触圧力はだ円体形に 分布し，その最大值は次式で求められる(11).

$$
p_{\max }=1 / \pi \cdot\left(1.5 \cdot E^{2} \cdot k w / R^{2}\right)^{1 / 3}
$$

ここで, $E$ は等価弾性係数, $R$ は等価半径(12) であ る. 等価半径 $\left(1 / r_{1}+1 / r_{2}\right)^{-1}$ は, 股関節のようなほほ同 じ半径の球 $\left(r_{1}=r\right)$ と球窝 $\left(r_{2}=-r-c\right)$ の接触では およそ半径 $r$ の 2 乗に比例し半径すきま (半径差) $c$ に反比例する。よって，半径すきまが一定であれば，

$$
p_{\max } \propto\left(w / r^{4}\right)^{1 / 3}
$$

となる，よって，接触面での破壊強度一定の条件では 次式が成立する。

$$
d \propto w^{1 / 4}
$$

$2 \cdot 4$ 沟浮性能関節摩擦面の潤滑は,スクイズ 流体潤滑と境界潤滑の混合潤滑により構成されている と考えられている(13)(14)．ただし，そのいずれが支配的 かは，明らかにされていない，支配的な因子が異なる と, 骨頭径に要求される大きさは，異なる。

スクイズ流体潤滑は，流体を介して摩擦面が押付ら れる際に, 粘性抵抗に由来する圧力が発生し, 固体表 面の接触を防ぐというメカニズムである，一般に，一 定荷重 $k w$ を受ける球と球窩の接近において，ある厚 さ $h$ までの潤滑膜のスクイズに要する時間は, 次式で 表わされる(15).

$$
t=-\frac{3 \pi \mu r^{4}}{k w c^{2}} \cdot \text { function }(h / c)
$$

この式で, $t$ はスクイズ時間, $\mu$ は, 粘性係数であ る、スクイズ時間は，それが長いほど潤滑膜厚さが厚 いという関係で潤滑膜厚さに 1 対 1 で対応するため, スクイズ潤滑効果がこのスクイズ時間で代表できる. よって, 半径すきまが一定ならば, 潤滑性能は $r^{4} / w$ に比例する。もし，同一のスクイズ潤滑性能を期待す るのであれば, $r$ は, $w$ の 1/4 乗に比例するはずであ る.よって，次式が成立する。

$$
d=2 r \propto w^{1 / 4}
$$

一方，境界潤滑が支配的な場合, Coulomb の摩㨲法 則により，摩擦係数は，速度や見掛けの接触面程に依 存せず一定である．摩擦モーメントは, テコの腕の長 さ，すなわち骨頭径に比例し，骨頭が大きいほど，関 節部の運動抵抗が大きくなる(13). また, Holm の乾燥 摩擦の法則により, 摩耗量は摩擦距離に比例するので 同じ関節運動による摩擦距離は骨頭径に比例して長く 
なり，摩耗量は増大する(13)。つまり，境界潤滑が支配 的であれば, 骨頭径は必ずしも体重に正相関しない。

以上のように，流体潤滑と境界潤滑で，骨頭径に要 求されるサイズは異なる。よって，骨頭径と体重の関 係を知ることは，潤滑状態を考察する上で有用とな る.

$2 \cdot 5$ その他これ以外の外力,すなわちねじり や曲げは，緒言で述べたように股関節部分には作用し ないと考えられる。よって，考虑の対象からはずす。

\section{3. 測 定 方 法}

国立科学博物館に保管されている哺乳類の乾燥骨格 標本の実測により，哺乳動物 13 種類, インドソウ,ク ロサイ, カバ, ウマ, キリン, バイソン, スイギュウ, ラクダ, ライオン, トナカイ, シェトランドポニー, オ ランウータン, チンパンジーの大腿骨頭径を求めた。

これらは，生前，いずれも上野動物園で飼育されてい た動物である，図 2 に示すようにスケールを横に置い て, 写真を撮影し，図3のように差し渡しの長さを読 み取った。

測定した各動物の体重については，これらの骨格標 本の生前のデータがないので, 文献 ${ }^{(16)}$ から動物の平均 体重を求めた.

ブタ,イヌ各 2 頭については，新鮮大腿骨を採取し て，軟骨を除いた大腿骨頭径を実測した。同じ個体の 体重も実測した。

ヒトの体重については厚生省の料(17)から, 我国 の国民の平均体重: 20 才以上男性で $63 \pm 9 \mathrm{~kg}$, 女性 で $52 \pm 8 \mathrm{~kg}$ を引用した。また，上トの乾燥骨の骨頭径 について, 慈恵医科大学の研究グループの実測結


$41 \pm 2 \mathrm{~mm}$ を, 引用した。

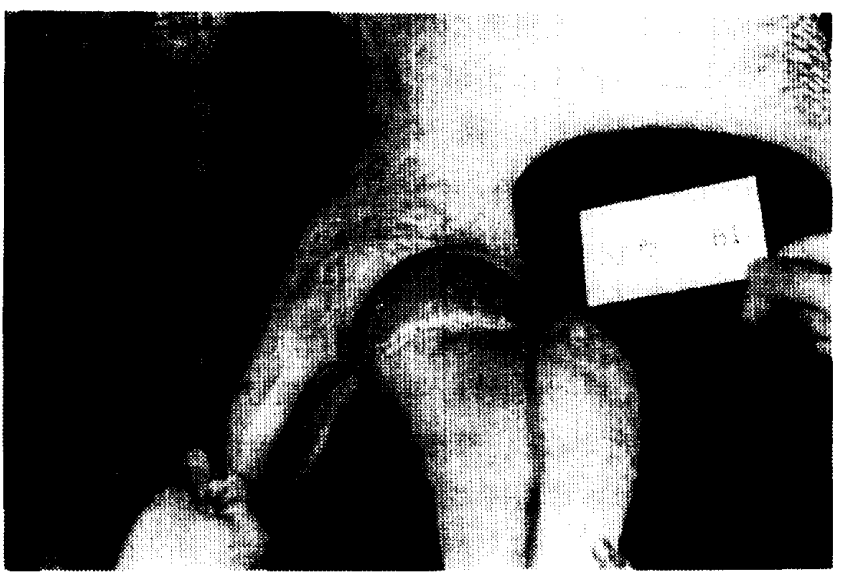

図 2 大腿骨頭径の計測の様子(インドソウの大泼骨頭の 計測)

\section{4. 結果}

以上に求めた各種の動物の骨頭の半径と体重を表 1 にまとめた。両者のべき乗関係を考察するために図 4 のように，両対数グラフにプロットした．対数グラフ 上では，体重と股関節骨頭径の間に，明白な正の相関 があった（相関係数 $0.98,1 \%$ 検定で有為）。

四足獣と二足獣の相違は重要と考えられるので，上 トを除外して回㷌直線（実線）およびデータの 95\%信 頼限界（点線）を求めて図示した．求めた両対数グラ フ上での回㷌直線は, 次式となった。

$$
d=7.4 w^{0.29}
$$

図 4 に示されるように，上卜は，男性女性ともに信 頼限界の外側にデータが分布した。これにより，ヒト の大腿骨頭径は，四足獣より有為に大きいことが示さ れた。

\section{5. 考宰}

四足哺乳動物の大腿骨頭径は体重の0.29 乗に比例 していることを示した。これは, 式（1）の 0.5 乗の関 係加遠く，式(4)や式(6)の 1/4 乗の関係に近い. よって，関節のサイズを決定する条件は，関節面の接 触圧力, あるいは，スクイズ流体潤滑性能であると推 論できる。また，骨頭径と体重に明白な正の相関があ ることから，関節の潤滑機棰において境界潤滑が支配 的でないことが推論できる。

接触圧力や，スクイズ流体潤滑性能一定の条件から $1 / 4$ 乗の関係を導くには式 $(2)$ ，（5)において，半径 すきまを一定と仮定しなければならない．動物の関節 は，図 5 のように，海綿骨の上に，軟骨が分布する構 造となっている，軟骨の弾性係数は，海綿骨の約 10 分 の 1 であることから，接触の問題を考える時は，軟骨 
の厚さと同等のすきまがあると考えるのが妥当であ る.

Simon(1970)は, マウス, ラット,イヌ,ヒッジ, ウ シにおいて関節軟骨の厚さと体重のアロメトリを調 べ,両者の相関を主張している(4).しかし, 彼のデー夕 においてイヌ以上の体格の動物では，その相関は明確 でない.また, 彼自身, 軟骨が厚くなると掘り起しの摩 擦抵抗 plowing が増大するので, 厚さに限界があるは ずだと述べている。一方，軟骨内部には血管が存在し

表 1 各種哺乳動物の大腿骨頭径 $d$ と体重 $w$

\begin{tabular}{llc}
\hline Species & $d_{\mathbf{m}} \mathbf{m m}$ & $\mathbf{w}, \mathbf{k g}$ \\
\hline Indian elephant & 95 & 4,500 \\
Black rhinoceros & 75 & 1,100 \\
Hippopotamus & 63 & 2,500 \\
Horse & 60 & 750 \\
Giraffe & 55 & 500 \\
Bison & 52 & 780 \\
Water buffalo & 52 & 1,000 \\
Camel & 50 & 570 \\
Lion & 38 & 170 \\
Reindeer & 32 & 135 \\
Shet land pony & 32 & 250 \\
Chimpanzee & 28 & 60 \\
Orangutan & 25 & 54 \\
Pig & 26 & 60 \\
Pig & 21 & 31 \\
Dog & 15 & 12 \\
Dog & 16 & 11 \\
Men & $63 \pm 9$ & $46 \pm 3$ \\
Women & $52 \pm 8$ & $41 \pm 2$ \\
\hline
\end{tabular}

ないので, 軟骨細胞への栄盖補給が, 専ら骨と関節液 からの拡散により行われる(8). そのため, ヒトの軟骨


件と考えられている(8). ヒトなみの大きさの動物で， すでに限界の厚さであるなら，大きな動物種では当然 これと同等の厚さと考えられ，同時に，接触問題の解 析の上では半径すきまは一定と考えられる。

イヌ、ブタでは，我々の実測した軟骨の晕さが，そ れぞれ約 $0.5,0.9 \mathrm{~mm}$ であった。このような小動物で は，以上の推論は成立しない。むしろ， $d / c$ が，一定に 近いと考えられる.その場合, 式 (4)，(6)の関係より 回㷌直線の傾きは，大きくなる.その影望により，本研 究の結果が, 0.25 より大きくなったと考えられる.

力学的条件からは, 大きさの最小限のみが導かれ る.よって，大きさが一義的に決まらず，因子を探るこ との意味がなくなる可能性がある。幸い,これについ ては以下に述べる生理的条件が，大きさの上限を規定 すると考えられる。

関節の軟骨面は，生体内の不連続面である，神経や 血行はもとより, あらゆる点で、体内の巨大な䡒裂と なっている.その結果, 関節の滑り面の周辺は, 栄意補 給や免疫反応の弱点となる。実際に，関節腔内で感染 を起こすと治疾し難い。また，大腿骨頭はいろいろな 原因で壊死しやすい。できれば，関節面の面積は小さ い方が生理的な状態が良好と考えられる。この考察か ら, 骨頭径は, 力学的な要請から決まる最低限の大き さになっていると考えられる。



図 4 両対数表示した各種哺乳動物の体重と大腿骨頭径の成係 


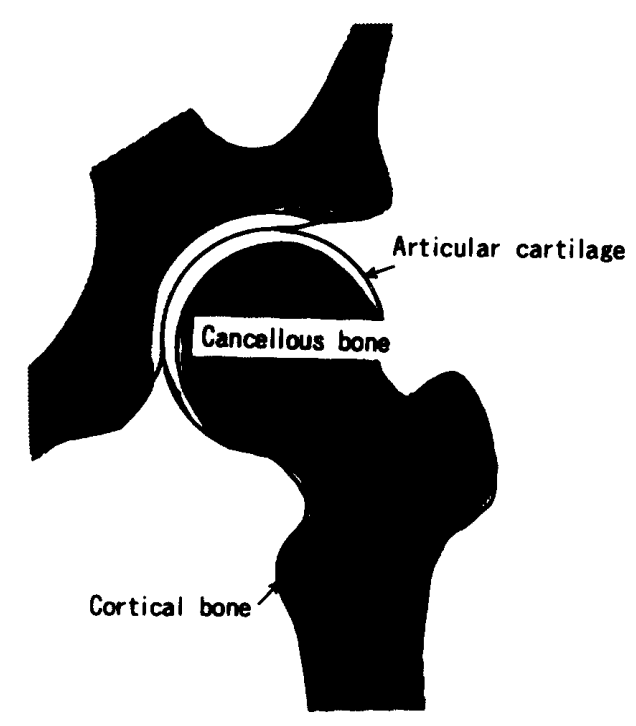

図 5 股関節の構造の概略断面図

関節摩㨲面を軟情が覆い，その下部に海綿骨，さら に，それを支えるように皮質骨が分布する

哺乳類 13 種の骨格標本は, 体格からみて幼弱個体 の可能性が高かった.よって, 体重の推定値が, 実際よ り大きい可能性があった。ただし，これらの体重の推 定值を, 表 1 の体重の $70 \%$ と補正した場合, 両対数グ ラフ上の回帰直線の傾きは，0.31に増加したに過ぎな かった。これは，補正したデー夕が大部分を占めてお り，それは，図4の上で左に平行移動するのみである から，全体への影響が小さかったためである。

この原因以外の, 平均值を個々の体重としたことに よる誤差は, 統計的なバラッキによるものである。そ れは，方向性がないので図 4 の関係に影響を与えるこ とはない.

ヒトの股関節骨頭径は, 有為にほかの動物より大き いことが示された。これは, 直立二足歩行により発揮 された特異性と考えられた。

人工股関節の骨頭径は, 現在, $22 \mathrm{~mm}$ から $36 \mathrm{~mm}$ のものが臨床で実用されている(13). その中で, 大きい 方がよいのか小さい方がよいのかが, 議論されてい る.筆者は，潤滑性能の向上を目指すには，接触圧力を 下げる必要があると主張して, 周囲の骨の掘削の条件 が許す限り，できるだけ大きな骨頭を用いるべきだと 主張している(19)(20). 動物股関節のアロメトリの因子に 関する本研究での推論は,この主張を支持するもので ある。また，ヒトの股関節骨頭径が，ほかの動物と比較 して有為に大きいという事実も，二足步行の力学条件
の旋しさと同時に, 大きなサイズの人工股関節の必要 性を示唆している。

\section{6. 結}

現生動物 15 種およびヒトについて大腿骨頭径と体 重の関係を調べた.その結果, 四足動物の骨頭径は, 体 重の 0.29 乗に比例することがわかった。この関係は， 関節摩摖面の接触圧力あるいはスクイズ流体潤滑性能 を一定とする条件から説明できると推論した。 また， ヒトの骨頭径は，ほかの四足動物と比較して有為に大 きく，二足步行による特殊化のためと推論した。

動物大腿骨頭径の測定に協力いただいた，国立科学 博物館主任研究官吉行瑞子博士および京セラ(株)滋賀 蒲生工場上野 勝君に深謝する。また，本研究に贵重 な助言をいただいた，富士写真フィルム(株)㱜田伸治 君に感謝する。

\section{文献}

(1) Gatilei G., (今野, 日田訳), 新科学対話 (原題, Discorsie dimonstrazioni matematische), (1638: 原害年号), (1937), 183, 岩波.

(2) Alexander, R. M., Size and shape, (1971), 1, Edward Arnold.

(3) Anderson, J. F., J. Zool. Lond., 207 (1985), 53.

(4) Simon, W. H., Arthritis Rheum., 13 (1970), 244.

(5) Charnley, J., Symp. Biomech. Inst. Mech. Engrs., Lond., (1959) 12.

（6）たとえば，森田・馬㴊・塚本，整形外科パイメカニクス， 7 (1985), 161.

（7）たと之ば，立石・白崎，機械技術研究所報告，130，(1984）, 7.

（8）たとえば, Freeman, M. A. R., Adult articular cartilage, (1973), 3, 277, Pitman Medical.

( 9 ) Simon, W. H., Arthritis Rheum., 14 (1971), 493.

（10）山田，人体の強度と老化，(1979），16. 日本放送出版協会.

(11) Timoshenko, S. P. and Goodier, J. N., Theory of elas. ticity, 3 rd Edit. (1970), 414, McGraw-Hill Kogakusha Ltd.

(12) Christensen, H., ASME J. Lub. Tech., 92F, (1970), 145.

（13）笹田・ほか 2 名、バイオトライボロジー, (1988), 60, 83,84, 産業図書。

(14) Unsworth, A.・ほか2名, ASME J. Lub.Tech., 97 F, (1975), 369.

(15) Moore, D. F., The friction and lubrication of elastomer, (1972), 122, Pergamon Press.

（16）たとえば, Meinertzhagen, C. R., Proc. Zool. Soc. Lond., A 108, (1938), 433.

（17）厘生省保健医湶局健康增進栄妻課監修，平成 2 年版国民 策费の現状, (1990), 117.

（18）伊丹，日整外会誌，43 (1969)， 1087.

（19）馬㴊・笹田, 潤滑, 23-7, (1978), 512.

（20）馬㴊・ほか 2 名，生体材料，8-4 (1990)，184. 